\title{
PERFORMA FOTOSINTESIS Kappaphycus sp. (strain Sumba) YANG DIUKUR BERDASARKAN EVOLUSI OKSIGEN TERLARUT PADA BEBERAPA TINGKAT SUHU DAN CAHAYA
}

\author{
Lideman")\# dan Asda Laining") \\ ") Balai Perikanan Budidaya Air Payau \\ B) Balai Penelitian dan Pengembangan Budidaya Air Payau
}

(Naskah diterima: 2 Februari 2015; Revisi final: 5 Maret 2015; Disetujui publikasi: 11 Maret 2015)

\begin{abstract}
ABSTRAK
Penelitian ini bertujuan untuk mengetahui pengaruh suhu dan cahaya terhadap laju fotosintesis Kappaphycus sp. (strain Sumba) yang diukur berdasarkan perubahan oksigen terlarut. Pengukuran laju fotosintesis Kappaphycus sp. pertama-tama dilakukan pada suhu $20^{\circ} \mathrm{C}, 24^{\circ} \mathrm{C}, 28^{\circ} \mathrm{C}$, dan $32^{\circ} \mathrm{C}$ pada tingkat cahaya 353 $\mu \mathrm{mol}$ photons $\mathrm{m}^{-2} \mathrm{~s}^{-1}$ untuk mendapatkan kurva fotosintesis versus suhu (kurva $P$ - $T$ ). Selanjutnya, pengukuran laju fotosintesis dilakukan pada suhu $20^{\circ} \mathrm{C}, 24^{\circ} \mathrm{C}$, dan $28^{\circ} \mathrm{C}$ dengan intensitas cahaya $9,22,46,58,87,137$, $245,353,487,608$, dan $789 \mu \mathrm{mol}$ photons $\mathrm{m}^{-2} \mathrm{~s}^{-1}$ dan juga pengukuran laju respirasi pada tingkat cahaya $0 \mu \mathrm{mol}$ photons $\mathrm{m}^{-2} \mathrm{~s}^{-1}$ untuk menghasilkan kurva fotosintesis versus cahaya (kurva $P-I$ ). Beberapa parameter fotosintesis yaitu: laju fotosintesis maksimum $\left(P_{\max }\right)$, koefisien fotosintesis $(\alpha)$, intensitas cahaya jenuh $\left(E_{\mathrm{k}}\right)$, dan intensitas cahaya kompensasi $\left(E_{c}\right)$ dihitung dengan cara memplotkan kurva $P$-I terhadap model persamaan regresi non linear $P=\left\{P_{\max } \times \tanh \left(\alpha / P_{\max } \times I\right)\right\}+R_{\mathrm{d}}$. Hasil yang diperoleh menunjukkan bahwa laju fotosintesis tertinggi sebesar $6,92 \mu \mathrm{g} \mathrm{O}_{2} \mathrm{~g}_{\mathrm{ww}}{ }^{-1} \mathrm{~min}^{-1}$ dicapai pada suhu $28^{\circ} \mathrm{C}$ dengan tingkat cahaya $353 \mu \mathrm{mol}$ photons $\mathrm{m}^{-2} \mathrm{~s}^{-1}$. Pada suhu $20^{\circ} \mathrm{C}, 24^{\circ} \mathrm{C}$, dan $28^{\circ} \mathrm{C}$, laju fotosintesis mencapai tingkat maksimum $\left(P_{\max }\right)$ pada intensitas cahaya $\left(E_{\mathrm{k}}\right) 86,1 ; 154,2$; dan $162,4 \mu \mathrm{mol}$ photons $\mathrm{m}^{-2} \mathrm{~s}^{-1}$. Suhu yang optimum untuk aktivitas fotosintesis berkorelasi erat dengan suhu pada lingkungan budidaya di alam.
\end{abstract}

KATA KUNCI: budidaya, cahaya, fotosintesis, Kappaphycus sp., suhu

ABSTRACT: Photosynthetic performances of Kappaphycus sp. (Sumba strain) as measured by dissolved oxygen evolution at several temperatures and light intensities. By: Lideman and Asda Laining

The objective of this experiment was to determine the effect of temperature and light intensity (irradiance) on the photosynthesis of Kappaphycus sp. (Sumba strain) as measured by evolution of dissolved oxygen. At the first experiment, photosynthetic rate was measured at temperatures of $20^{\circ} \mathrm{C}, 24^{\circ} \mathrm{C}, 28^{\circ} \mathrm{C}$, and $32^{\circ} \mathrm{C}$ at irradiance of $353 \mu \mathrm{mol}$ photons $\mathrm{m}^{-2} \mathrm{~s}^{-1}$ in order to obtain photosynthesis versus temperature curve ( $P$-T curve). At temperatures of $20^{\circ} \mathrm{C}, 24^{\circ} \mathrm{C}$, and $28^{\circ} \mathrm{C}$, measuring of photosynthetic rate was carried out at irradiance of $9,22,46,58,87,137,245,353,487$, 608, and $789 \mu \mathrm{mol}$ photons $\mathrm{m}^{-2} \mathrm{~s}^{-1}$ and also measuring of respiration rate was at $0 \mu \mathrm{mol}$ photons $\mathrm{m}^{-2} \mathrm{~s}^{-1}$ in order to generate photosynthesis versus irradiance curve (P-I curve). Several photosynthetic parameters such as maximum photosynthetic rate $\left(P_{\max }\right)$, photosynthetic coefficient $(\alpha)$, saturation irradiance $\left(E_{k}\right)$ and compensation irradiance $\left(E_{c}\right)$ were estimated by plotting $P$-I curve to non linear regression model of $P=\left\{P_{\max } \times \tanh \left(\alpha / P_{\max } \times I\right)\right\}+R_{d}$. The result showed that the highest photosynthetic rate of $6.92 \mu \mathrm{g} \mathrm{O} \mathrm{g}_{w w}{ }^{-1} \mathrm{~min}^{-1}$ was obtained at temperature of $28^{\circ} \mathrm{C}$ with light intensity of $353 \mu \mathrm{mol}$ photons $\mathrm{m}^{-2} \mathrm{~s}^{-1}$. At temperatures of $20^{\circ} \mathrm{C}, 24^{\circ} \mathrm{C}$, and $28^{\circ} \mathrm{C}$, photosynthesis rate reachs their maximum value $\left(P_{\max }\right)$ at irradiance $\left(E_{k}\right)$ of 86.6, 154.2, and $162.4 \mu \mathrm{mol}$ photons $\mathrm{m}^{-2} \mathrm{~s}^{-1}$, respectively. Optimum temperature for photosynthesis activity was related to temperature in their natural habitat.

KEYWORDS: $\quad$ aquaculture, light intensity, photosynthesis, Kappaphycus sp., temperature

\# Korespondensi: Balai Perikanan Budidaya Air Payau.

Ds. Bontole Kec. Galesong Selatan Kab. Takalar, Ujung Pandang

92254. Indonesia. Tel. (0411)720730

E-mail: lidemanz@yahoo.com 


\section{PENDAHULUAN}

Genus Eucheuma dan Kappaphycus (red algae) adalah rumput laut yang mempunyai nilai ekonomis yang tinggi karena kandungan karagenannya. Karagenan ini digunakan pada berbagai industri seperti: industri makanan, kosmetik, tekstil, dan farmasi karena dapat berfungsi sebagai pengental, pengemulsi, penggumpal, dan pengisi material. Sejak tahun 2008, Indonesia merupakan negara penghasil terbesar cottonii (Kappaphycus alvarezii) di dunia dan pada tahun 2009, sebanyak 94\% produksi cottonii di dunia berasal dari Indonesia dan Filipina (Bixler \& Porse, 2011).

Budidaya Kappaphycus alvarezii secara komersil sudah berkembang di Filipina sejak tahun 1960-an dengan menggunakan varietas lokal dari alam (Parker, 1974). Budidaya Kappaphycus ini juga berhasil dikembangkan di Cina (Wu et al., 1989), Madagascar (Mollion \& Braud, 1993) dan Vietnam (Ohno et al., 1996). Di Indonesia, berbagai strain Kappaphycus alvarezii telah dibudidayakan di antaranya adalah: Sakol, Tambalang, Cottonii, dan Sumba. Strain Sumba diduga berasal dari Pulau Sumba, Nusa Tenggara Timur, sedangkan Sakol dan Tambalang berasal dari Filipina yang diintroduksikan ke Indonesia pada tahun 1990-an.

Beberapa studi mengenai Eucheuma dan generanya telah banyak dilakukan meliputi: karakteristik pertumbuhan, kandungan karagenan, dan konservasi (Dawes et al., 1974; Paula et al., 2001; 2002; Hung et al., 2009). Studi mengenai fisiologi banyak dilakukan pada strain-strain yang berasal dari alam terutama yang berasal dari Filipina dan sangat terbatas dilakukan pada strain hasil budidaya.

Salah satu aspek fisiologis yang perlu dikaji pada Eucheuma adalah laju fotosintetis, proses yang sangat penting dalam pertumbuhan rumput laut untuk mengonversi cahaya menjadi energi kimia seperti gula dan molekul bahan organik (Lobban \& Harrison, 1997). Faktor utama yang memengaruhi laju fotosintesis adalah: suhu dan cahaya. Studi mengenai performa fotosintesis Kappaphycus sp. (strain Sumba) dengan metode evolusi oksigen pada suhu dan cahaya yang berbeda perlu dilakukan untuk dijadikan acuan dalam mengoptimalkan sistem budidayanya. Penelitian ini bertujuan untuk mengetahui pengaruh suhu dan cahaya terhadap laju fotosintesis Kappaphycus sp. (strain Sumba) yang diukur berdasarkan perubahan oksigen terlarut.

\section{BAHAN DAN METODE}

\section{Koleksi Sampel}

Sampel rumput laut yang digunakan pada penelitian ini adalah Kappaphycus sp. (strain Sumba) (Gambar 1), famili Solieriaceae (Rhodophyta) yang dibudi-

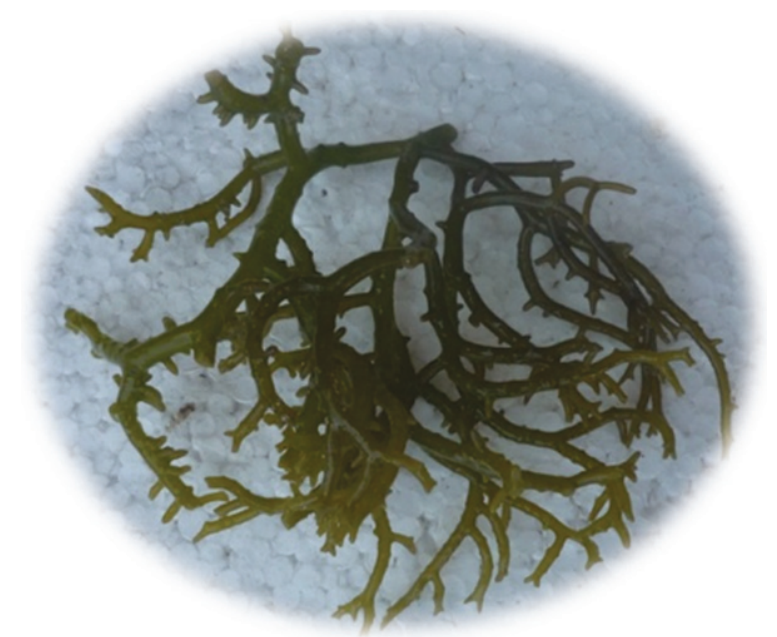

Gambar 1. Kappaphycus sp. (strain Sumba) hasil budidaya

Figure 1. Cultured Kappaphycus sp. (Sumba strain)

dayakan di Desa Punaga Kabupaten Takalar, Sulawesi Selatan (5³4'56.62"N, 119²7'42.56"E). Rumput laut yang telah diambil ditampung pada wadah styrofoam yang berisi air laut lalu dibawa ke Laboratorium $M a-$ rine Botany, Fakultas Perikanan, Kagoshima University, Japan. Selama pengangkutan, suhu dalam styrofoam dipertahankan kurang lebih $20^{\circ} \mathrm{C}$. Selama proses adaptasi di laboratorium, Kappaphycus sp. dipelihara dalam akuarium berukuran 2,0 $\mathrm{m}$ x 1,0 m x 0,5 m dengan salinitas 30 ppt; pH 8,0; cahaya $90 \mu \mathrm{mol}$ photons $\mathrm{m}^{-2} \mathrm{~s}^{-1}$, suhu $20^{\circ} \mathrm{C}$ dan siklus cahaya 14 jam terang : 10 jam gelap.

\section{Pengukuran Laju Fotosintesis pada Suhu yang Berbeda}

Pengukuran laju fotosintesis ini dilakukan pada empat tingkat suhu yaitu: $20^{\circ} \mathrm{C}, 24^{\circ} \mathrm{C}, 28^{\circ} \mathrm{C}$, dan $32^{\circ} \mathrm{C}$ dengan cahaya (irradiance) sebesar $353 \mu \mathrm{mol}$ photons $\mathrm{m}^{-2} \mathrm{~s}^{-1}$. Tingkat cahaya ini lebih tinggi dari tingkat saturasi cahaya (saturation irradiance; $E_{\mathrm{k}}$ ) yang diperoleh dari kurva photosynthetic versus irradiance $(P-I)$ menggunakan lampu metal-halide sebagai sumber cahaya yang telah dicoba pada berbagai makro-alga (Nishihara et al., 2004). Percobaan ini dilakukan dengan empat ulangan.

Pengukuran irradiance dilakukan dengan menggunakan sensor quantum pada air LI-193SA (LI-250; Li-Cor Inc., Nebraska). Suhu diatur dan dipertahankan dengan menggunakan pengontrol suhu air (Coolnit CL-80F, Taitec, Inc., Tokyo). Laju fotosintesis dihitung berdasarkan konsentrasi oksigen terlarut (dissolved oxygen; $\mathrm{mg} / \mathrm{L}$ ) tiap lima menit selama 30 menit. Setiap pengukuran, sampel diaklimatisasi selama 30 menit. Oksigen terlarut diukur menggunakan prob polarographic DO meter (Model 58, and 5100, YSI Incorporated, Ohio) (Gambar 2). 


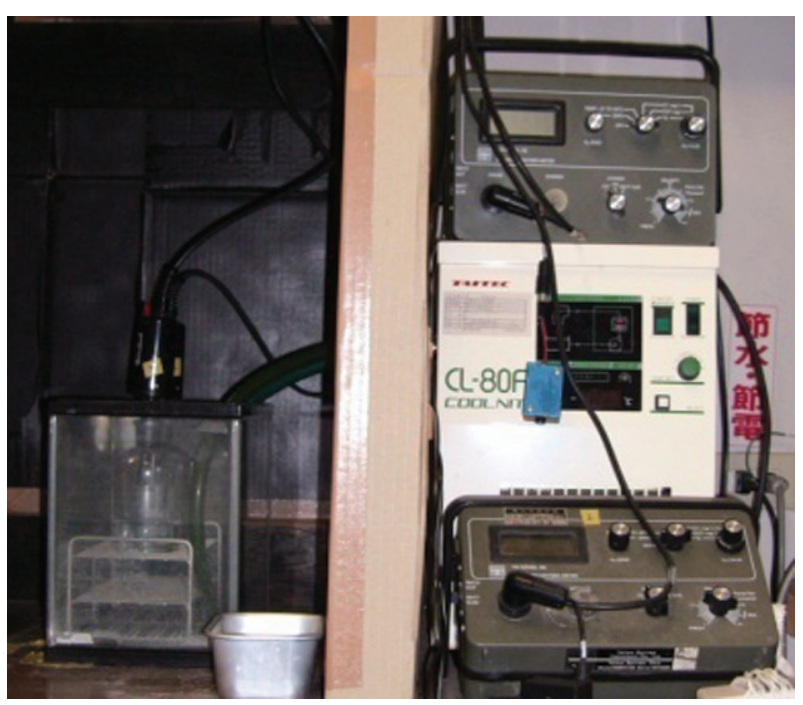

Gambar 2. Peralatan yang digunakan untuk mengukur evolusi oksigen terlarut, antara lain: DO meter, pengatur suhu air, akuarium, botol BOD yang berisi air laut steril, probe DO meter

Figure 2. Equipments used for measuring evolution of dissolved oxygen (DO): DO meter, water temperature regulator, aquarium, BOD bottle containing sterilized sea water, and DO meter probe

Eksplan yang digunakan pada penelitian ini berukuran 0,3-0,5 g basah $\left(\mathrm{g}_{\mathrm{ww}}\right)$. Eksplan yang telah dipotong dari talusnya diaklimatisasi selama semalam dengan air laut steril di dalam inkubator (Muraoka et al., 1998; Serisawa et al., 2001). Sebelum pengukuran dimulai, eksplan dimasukan ke dalam botol BOD yang berisi 99,2 mL air laut steril. Sensor DO diletakkan dalam air laut steril tersebut tanpa gelembung udara (bubbles), kemudian air laut steril tersebut diputar dengan mengunakan stirer yang ada pada prob DO meter. Pengukuran laju fotosintesis Kappaphycus sp. selanjutnya dilakukan pada suhu yang telah ditentukan yaitu $20^{\circ} \mathrm{C}, 24^{\circ} \mathrm{C}, 28^{\circ} \mathrm{C}$, dan $32^{\circ} \mathrm{C}$ pada tingkat cahaya $353 \mu \mathrm{mol}$ photons $\mathrm{m}^{-2} \mathrm{~s}^{-1}$ untuk mendapatkan kurva fotosintesis versus suhu (kurva $P-T$ ).

\section{Pengukuran Laju Fotosintesis pada Cahaya (Irradiance) yang Berbeda}

Pengukuran laju fotosintesis pada percobaan ini dilakukan pada sebelas tingkat cahaya yaitu: 9, 22, 46, $58,87,137,245,353,487,608$, and $789 \mu \mathrm{mol}$ photons $\mathrm{m}^{-2} \mathrm{~s}^{-1}$ dan laju respirasi diukur pada intensitas cahaya 0 photons $\mathrm{m}^{-2} \mathrm{~s}^{-1}$. Pengukuran laju fotosintesis dan laju respirasi ini dilakukan pada tiga suhu yang berbeda yaitu $20^{\circ} \mathrm{C}, 24^{\circ} \mathrm{C}$, dan $28^{\circ} \mathrm{C}$. Pengukuran dilakukan dengan empat ulangan. Metode pengukuran laju fotosintesis pada percobaan ini sama dengan metode sebelumnya yaitu dengan mengukur konsentrasi oksigen terlarut ( $\mathrm{mg} / \mathrm{L}$ ) setiap lima menit selama 30 menit dengan menggunakan DO meter.

Parameter-parameter fotosintesis diperoleh dengan cara memplotkan model P-I (Photosynthesis versus Irradiance) terhadap kurva P-I (Gambar 3) untuk

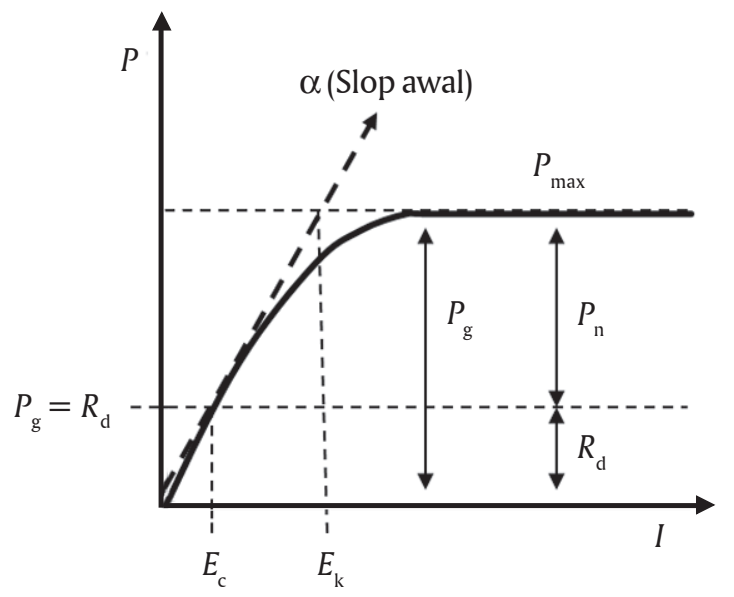

Sumber (Source): Loban \& Harrison (1997)

Gambar 3. Model kurva $P$-I yang digunakan untuk men-estimasi parameter-parameter fotosintesis. $P=$ Laju fotosintesis, $I=$ Intensitas cahaya, $P_{\mathrm{n}}=$ Laju fotosintesis bersih, $P_{\max }=$ Laju fotosintesis maksimum (kondisi di mana fotosintesis mengalami kejenuhan), $R_{\mathrm{d}}=$ Laju respirasi, $\alpha=$ Slop awal laju fotosintesis (koefisien fotosintesis), $E_{\mathrm{k}}=$ Cahaya jenuh $\left(P_{\max } / \alpha\right.$; adalah cahaya yang menyebabkan fotosintesis mengalami kejenuhan ( $\alpha$ bersilangan dengan $\left.P_{\max }\right), E_{\mathrm{c}}=$ Cahaya kompensasi $\left(P_{\mathrm{g}}=R_{\mathrm{d}}\right.$ atau $R_{\mathrm{d}} / \alpha$; adalah cahaya yang menyebabkan laju fotosintesis sama dengan laju respirasi)

Figure 3. $\quad$ P-I curve model used for estimating photosynthetic parameters. $P=$ Photosynthetic rate, $I=$ Irradiance, $P_{\mathrm{n}}=$ Net photosynthetic rate, $P_{\max }=$ Maximum photosynthetic rate, $R_{\mathrm{d}}=$ Respiration rate, $\alpha=$ Initial slope (coefficient photosynthesis), $E_{\mathrm{k}}=$ Saturation irradiance $\left(P_{\max } / \alpha\right), E_{\mathrm{c}}=$ Compensation irradiance $\left(P_{\mathrm{g}}=R_{\mathrm{d}}\right.$ or $\left.R_{\mathrm{d}} / \alpha\right)$ 
tiap tingkatan suhu dengan menggunakan regresi non linear least squares berdasarkan persamaan berikut:

$$
P=\left\{P_{\text {max }} \times \tanh \left(\alpha / P_{\text {max }} \times I\right)\right\}+R_{\mathrm{d}}
$$

di mana:

$P=$ Laju produksi $\mathrm{O}_{2}, P_{\max }=$ Laju produksi maksimum $\mathrm{O}_{2}$, $\alpha=$ Initial slope (kemiringan awal) dari kurva fotosintesis versus cahaya (kurva $P-I), I=$ Intensitas cahaya (irradiance), dan $R_{\mathrm{d}}=$ Laju respirasi gelap (Jassby \& Platt, 1976; Henley, 1993). Saturation irradiance $\left(E_{\mathrm{k}}\right)$ dihitung dengan rumus: $P_{\max } / \alpha$ dan compensation irradiance $\left(E_{\mathrm{c}}\right)$ dihitung dengan rumus: $R_{\mathrm{d}} / \alpha$ (Schubert et al., 2006).

Kondisi penelitian untuk pengukuran laju fotosintesis pada beberapa tingkat suhu dan cahaya dapat dilihat pada Tabel 1 .

\section{HASIL DAN BAHASAN}

\section{Pengaruh Suhu Terhadap Laju Fotosintesis}

Laju fotosintesis Kappaphycus sp. pada suhu $20^{\circ} \mathrm{C}$, $24^{\circ} \mathrm{C}, 28^{\circ} \mathrm{C}$, dan $32^{\circ} \mathrm{C}$ dengan tingkat irradiance 353 $\mu$ mol photons $\mathrm{m}^{-2} \mathrm{~s}^{-1}$ (Gambar 4). Laju fotosintesis tertinggi adalah $6,92 \mu \mathrm{g} \mathrm{O}_{2} \mathrm{~g}_{\mathrm{ww}}{ }^{-1} \mathrm{~min}^{-1}$ terjadi pada suhu $28^{\circ} \mathrm{C}$, kemudian diikuti oleh 5,90 dan 5,73 $\mu \mathrm{g} \mathrm{O}_{2}$ $\mathrm{g}_{\mathrm{ww}}{ }^{-1} \mathrm{~min}^{-1}$ berturut-turut terjadi pada suhu $32^{\circ} \mathrm{C}$ dan $24^{\circ} \mathrm{C}$. Selanjutnya, laju fotosintesis terendah adalah 2,68 $\mu \mathrm{g} \mathrm{O}_{2} \mathrm{~g}_{\mathrm{ww}}{ }^{-1} \mathrm{~min}^{-1}$ terjadi pada suhu $20^{\circ} \mathrm{C}$.

\section{Pengaruh Cahaya Terhadap Laju Fotosintesis}

Laju fotosintesis Kappaphycus sp. dapat dimodel dengan bentuk hyperbolic tangent dari persamaan

Tabel 1. Kondisi penelitian untuk mengetahui pengaruh suhu dan cahaya terhadap laju fotosintesis Kappaphycus sp. Table 1. Experiment condition to know effect of temperature and irradiance on photosynthetic rate of Kappaphycus sp.

\begin{tabular}{|c|c|c|}
\hline \multirow{2}{*}{$\begin{array}{l}\text { Kondisi } \\
\text { Condition }\end{array}$} & \multicolumn{2}{|c|}{$\begin{array}{l}\text { Pengaruh suhu dan cahaya terhadap laju fotosintesis } \\
\text { Effect of temperature and light intensity on photosynthetic rate }\end{array}$} \\
\hline & $\begin{array}{l}\text { Pengaruh suhu } \\
\text { Temperature effect }\end{array}$ & $\begin{array}{l}\text { Pengaruh cahaya } \\
\text { Irradiance effect }\end{array}$ \\
\hline Suhu (Temperature $)\left({ }^{\circ} \mathrm{C}\right)$ & $20,24,28,32$ & $20,24,28$ \\
\hline $\begin{array}{l}\text { Intensitas cahaya (Irradiance) }(\mu \mathrm{mol} \\
\left.\text { photons } \mathrm{m}^{-2} \mathrm{~s}^{-1}\right)\end{array}$ & 353 & $\begin{array}{l}0,9,22,46,58,87,137 \\
245,353,487,608,789\end{array}$ \\
\hline Bobot eksplan (Explant weight) (g) & $0.3-0.5$ & $0.3-0.5$ \\
\hline Parameter (Parameters) & $(m)$ & 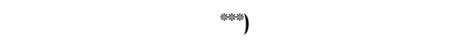 \\
\hline Media (Medium) & Air laut steril (Sterilized sea water) & Air laut steril (Sterilized sea water) \\
\hline Ulangan (Replication) & 4 ulangan (4 replicates) & 4 ulangan (4 replicates) \\
\hline
\end{tabular}

Keterangan (Note): - Evolusi DO tiap lima menit selama 30 menit (DO evolution every five minutes for 30 minutes)

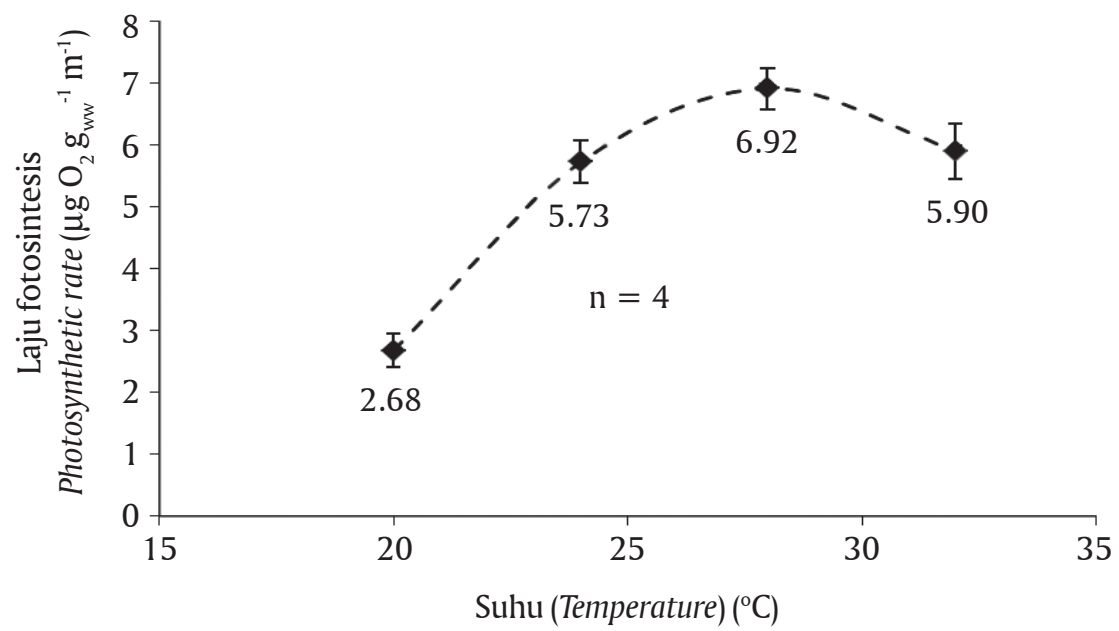

Gambar 4. Laju fotosintesis Kappaphycus sp. pada suhu $20^{\circ} \mathrm{C}, 24^{\circ} \mathrm{C}, 28^{\circ} \mathrm{C}$, dan $32^{\circ} \mathrm{C}$ (kurva $P$ - T) dengan tingkat irradiance $353 \mu \mathrm{mol}$ photons $\mathrm{m}^{-2} \mathrm{~s}^{-1}$. Bar adalah standar deviasi. Pengukuran laju fotosintesis dilakukan dengan empat ulangan

Figure 4. Photosynthetic rate of Kappaphycus sp. at temperatures of $20^{\circ} \mathrm{C}, 24^{\circ} \mathrm{C}, 28^{\circ} \mathrm{C}$, and $32^{\circ} \mathrm{C}$ (P-T curve) at irradiance of $353 \mu \mathrm{mol}$ photons $\mathrm{m}^{-2} \mathrm{~s}^{-1}$. Bar indicates the standard deviation. Photosynthetic rate was measured in four replicates 
yang didasarkan pada kurva $P-I$. Laju respirasi $\left(R_{\mathrm{d}}\right)$ Kappaphycus sp. pada suhu $20^{\circ} \mathrm{C}, 24^{\circ} \mathrm{C}$, dan $28^{\circ} \mathrm{C}$ berturut-turut adalah $-0,47 ;-0,73$ dan $-1,18 \mu \mathrm{g} \mathrm{O}_{2} \mathrm{~g}_{\mathrm{ww}}{ }^{-1}$ $\mathrm{min}^{-1}$. Selanjutnya, laju fotosintesis pada suhu $20^{\circ} \mathrm{C}$ meningkat tajam mulai irradiance 9 sampai $137 \mu \mathrm{mol}$ photons $\mathrm{m}^{-2} \mathrm{~s}^{-1}$ dan meningkat perlahan sampai irradiance mencapai $245 \mu \mathrm{mol}$ photons $\mathrm{m}^{-2} \mathrm{~s}^{-1}$ (Gambar 5). Pada suhu $24^{\circ} \mathrm{C}$ dan $28^{\circ} \mathrm{C}$, laju fotosintesis meningkat tajam melalui irradiance 9 sampai $245 \mu \mathrm{mol}$ photons $\mathrm{m}^{-2} \mathrm{~s}^{-1}$ dan meningkat perlahan sampai irradiance mencapai $353 \mu \mathrm{mol}$ photons $\mathrm{m}^{-2} \mathrm{~s}^{-1}$ (Gambar 6 dan 7). Laju fotosintesis maksimum $\left(P_{\max }\right)$ adalah 3,$2 ; 6,2$; dan
$7,2 \mu \mathrm{g} \mathrm{O}_{2} \mathrm{~g}_{\mathrm{ww}}^{-1} \mathrm{~min}^{-1}$ berturut-turut pada suhu $20^{\circ} \mathrm{C}$, $24^{\circ} \mathrm{C}$, dan $28^{\circ} \mathrm{C}$.

\section{Parameter Fotosintesis Kappaphycus sp.}

Parameter-parameter fotosintesis yang diperoleh dari penelitian ini secara lengkap dapat dilihat pada Tabel 2. Parameter-parameter fotosintesis yang diperoleh dari model yang diplotkan pada kurva $P-I$ (Gambar 8) menunjukkan bahwa laju fotosintesis maksimum $\left(P_{\max }\right)$ adalah 3,$2 ; 6,2$; dan $7,6 \mu \mathrm{g} \mathrm{O}_{2} \mathrm{~g}_{\mathrm{ww}}{ }^{-1}$ $\min ^{-1}$ berturut-turut untuk suhu $20^{\circ} \mathrm{C}, 24^{\circ} \mathrm{C}$, dan $28^{\circ} \mathrm{C}$. Selanjutnya, saturation irradiance $\left(E_{\mathrm{k}}\right)$ berturut-turut

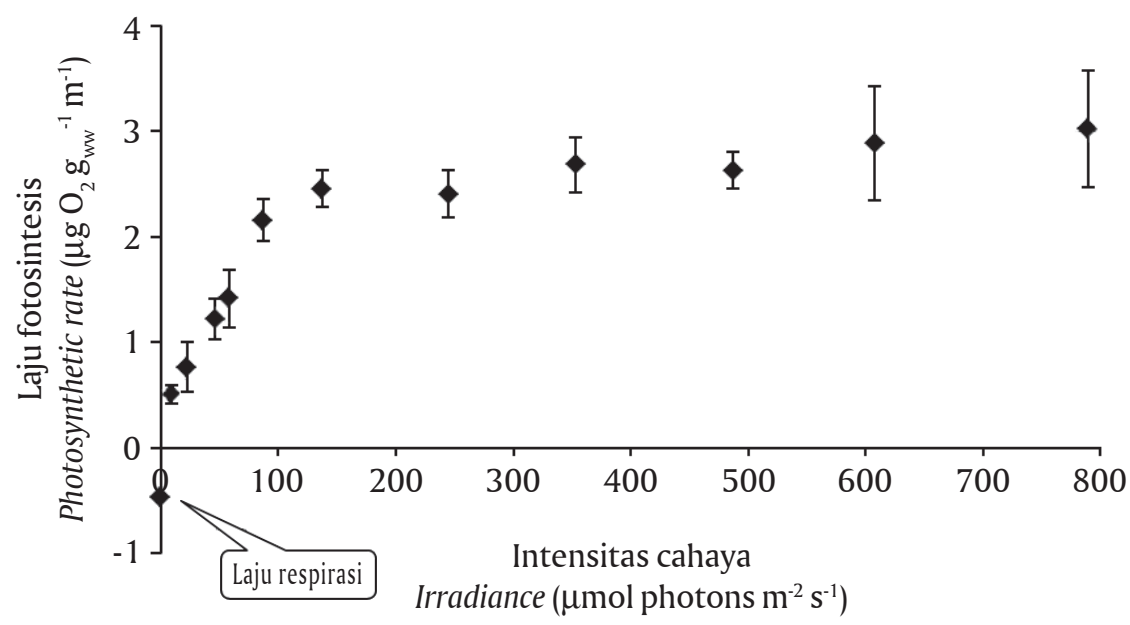

Gambar 5. Laju fotosintesis dan respirasi Kappaphycus sp. pada beberapa tingkat cahaya (kurva fotosintesis versus cahaya; kurva $P-I$ ) dan suhu $20^{\circ} \mathrm{C}$. Bar adalah standar deviasi. Pengukuran laju fotosintesis dan respirasi dilakukan empat ulangan

Figure 5. Photosynthetic rate and respiration rate of Kappaphycus sp. at several light intensity (photosynthesis versus irradiance curve; P-I curve) and temperature of $20^{\circ} \mathrm{C}$. Bar indicates the standard deviation. Photosynthetic rate and respiration rate were measured in four replicates

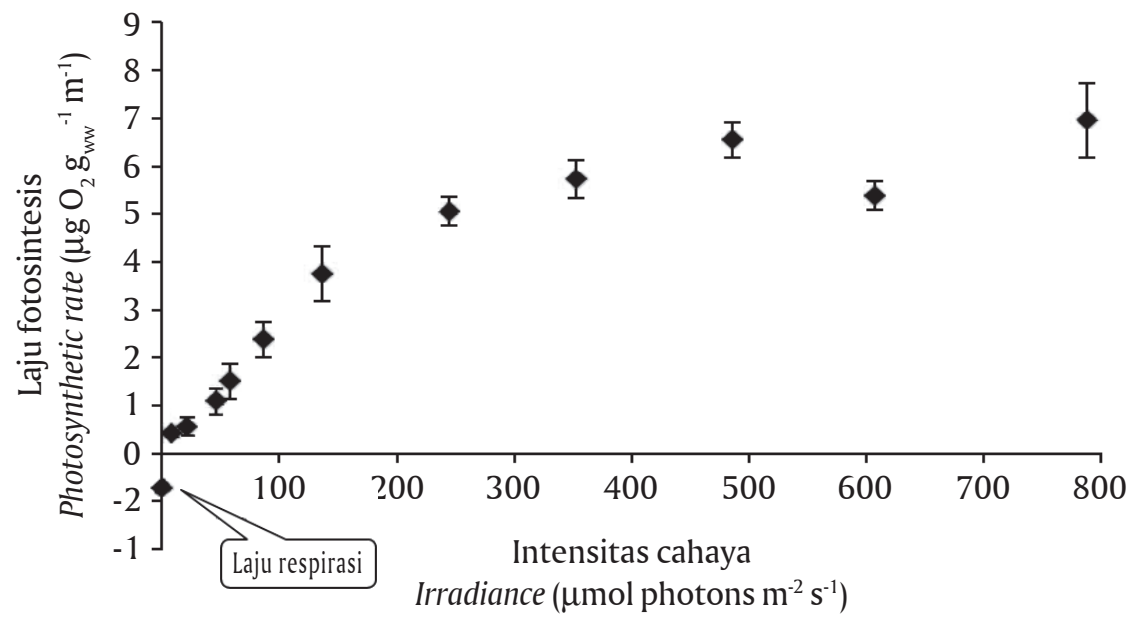

Gambar 6. Laju fotosintesis dan respirasi Kappaphycus sp. pada beberapa tingkat cahaya (kurva fotosintesis versus cahaya; kurva $P-I$ ) dan suhu $24^{\circ} \mathrm{C}$. Bar adalah standar deviasi. Pengukuran laju fotosintesis dan respirasi dilakukan empat ulangan

Figure 6. Photosynthetic rate and respiration rate of Kappaphycus sp. at several light intensity (photosynthesis versus irradiance curve; $P$-I curve) and temperature of $24^{\circ} \mathrm{C}$. Bar indicates the standard deviation. Photosynthetic rate and respiration rate were measured in four replicates 


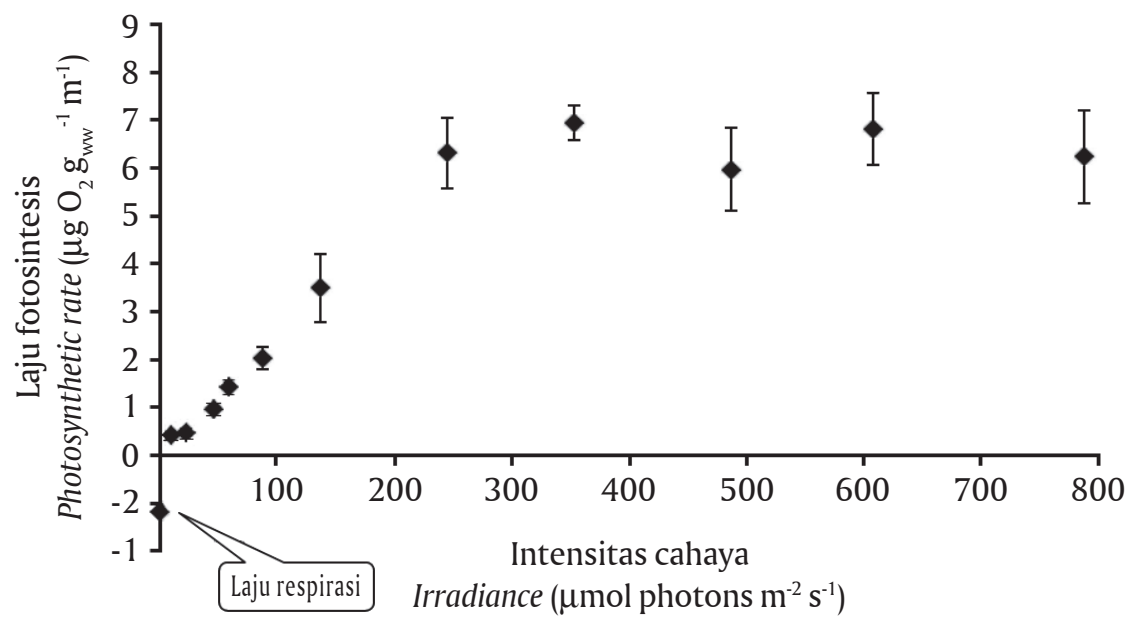

Gambar 7. Laju fotosintesis dan respirasi Kappaphycus sp. pada beberapa tingkat cahaya (kurva fotosintesis versus cahaya; kurva $P-I$ ) dan suhu $28^{\circ} \mathrm{C}$. Bar adalah standar deviasi. Pengukuran laju fotosintesis dan respirasi dilakukan empat ulangan

Figure 7. Photosynthetic rate and respiration rate of Kappaphycus sp. at several light intensity (photosynthesis versus irradiance curve; P-I curve) and temperature of $28^{\circ} \mathrm{C}$. Bar indicates the standard deviation. Photosynthetic rate and respiration rate were measured in four replicates

Tabel 2. Estimasi parameter fotosintesis Kappaphycus sp. pada beberapa tingkat suhu $20^{\circ} \mathrm{C}, 24^{\circ} \mathrm{C}$ dan $28^{\circ} \mathrm{C}$ Table 2. Estimated photosynthetic parameters of Kappaphycus sp. at temperature of $20^{\circ} \mathrm{C}, 24^{\circ} \mathrm{C}$, and $28^{\circ} \mathrm{C}$

\begin{tabular}{|c|c|c|c|}
\hline \multirow{2}{*}{$\begin{array}{l}\text { Parameters fotosintesis } \\
\text { Photosynthetic Parameters }\end{array}$} & \multicolumn{3}{|c|}{ Suhu (Temperature ) $\left({ }^{\circ} \mathrm{C}\right)$} \\
\hline & 20 & 24 & 28 \\
\hline $\begin{array}{l}P_{\max }=\text { Laju fotosintesis maksimum (Maximum photosynthetic rate ) } \\
\left(\mu g \mathrm{O}_{2} \mathrm{~g}_{\mathrm{ww}}^{-1} \mathrm{~min}^{-1}\right)\end{array}$ & 3.2 & 6.2 & 7.6 \\
\hline$R_{\mathrm{d}}=$ Laju respirasi (Respiration rate $)\left(\mu \mathrm{g} \mathrm{O} \mathrm{O}_{\mathrm{ww}}{ }^{-1} \min ^{-1}\right)$ & -0.47 & -0.73 & -1.18 \\
\hline $\begin{array}{l}\alpha=\text { Slop awal (koefisien fotosintesis) (Initial slope (coefficient photo- } \\
\text { synthesis)) }\end{array}$ & 0.0372 & 0.0402 & 0.0468 \\
\hline $\begin{array}{l}E_{\mathrm{k}}=\text { Intensitas cahaya jenuh (Saturation irradiance) ( } \mu \mathrm{mol} \text { photons } \\
\left.\mathrm{m}^{-2} \mathrm{~s}^{-1}\right)\end{array}$ & 86.1 & 154.2 & 162.4 \\
\hline $\begin{array}{l}E_{\mathrm{c}}=\text { Intensitas cahaya kompensasi (Compensation irradiance) }(\mu \mathrm{mol} \\
\left.\text { photons } \mathrm{m}^{-2} \mathrm{~s}^{-1}\right)\end{array}$ & 12.6 & 18.2 & 25.2 \\
\hline
\end{tabular}

Keterangan (Note):

$E_{\mathrm{k}}$ adalah intensitas cahaya yang menyebabkan laju fotosintesis mencapai tingkat jenuh, dan $E_{\mathrm{c}}$ adalah intensitas cahaya yang menyebabkan laju fotosintesis sama dengan laju respirasi $\left(E_{\mathrm{k}}\right.$ is light intensity that causing photosynthetic rate become saturating and $E_{\mathrm{c}}$ is light intensity that causing equal level of photosynthetic rate and respiration rate)

untuk suhu $20^{\circ} \mathrm{C}, 24^{\circ} \mathrm{C}$, dan $28^{\circ} \mathrm{C}$ adalah 86,$1 ; 154,2$; dan $162,4 \mu \mathrm{mol}$ photons $\mathrm{m}^{-2} \mathrm{~s}^{-1}$. Sementara itu, compensation irradiance $\left(E_{c}\right)$ adalah 12,$6 ; 18,2 ; 25,2 \mu \mathrm{mol}$ photons $\mathrm{m}^{-2} \mathrm{~s}^{-1}$ untuk suhu berturut-turut $20^{\circ} \mathrm{C}, 24^{\circ} \mathrm{C}$, dan $28^{\circ} \mathrm{C}$.

Proses fotosintesis Kappaphycus sp. yang paling aktif terjadi pada suhu $28^{\circ} \mathrm{C}$ dibandingkan dengan suhu $32^{\circ} \mathrm{C}, 24^{\circ} \mathrm{C}$, dan $20^{\circ} \mathrm{C}$. Suhu optimum hasil penelitian ini termasuk dalam kisaran suhu optimum $22^{\circ} \mathrm{C}-33^{\circ} \mathrm{C}$ untuk aktivitas fotosintesis Kappaphycus sp. yang diukur menggunakan chlorophyll fluorescence menggunakan alat Pulse Aplitude Modulation (PAM)- chlorophyll fluorometry (Lideman et al., 2013). Studi lainnya menunjukkan bahwa K. alvarezii mempunyai laju pertumbuhan tertinggi pada suhu $25^{\circ} \mathrm{C}-28^{\circ} \mathrm{C}$ (Ohno et al., 1994) dan laju fotosintesis untuk Eucheuma denticulatum terjadi pada kisaran suhu $23^{\circ} \mathrm{C}-32^{\circ} \mathrm{C}$ (Lideman et al., 2013).

Laju fotosintesis tertinggi terjadi pada suhu $28^{\circ} \mathrm{C}$ yang diperoleh pada penelitian ini sangat berhubungan dengan suhu di perairan laut tropis Indonesia yang berkisar $25^{\circ} \mathrm{C}-30^{\circ} \mathrm{C}$ (Tomascik et al., 1997) yang merupakan habitat Kappaphycus sp. Hubungan yang erat antara suhu optimum untuk proses fotosintesis 


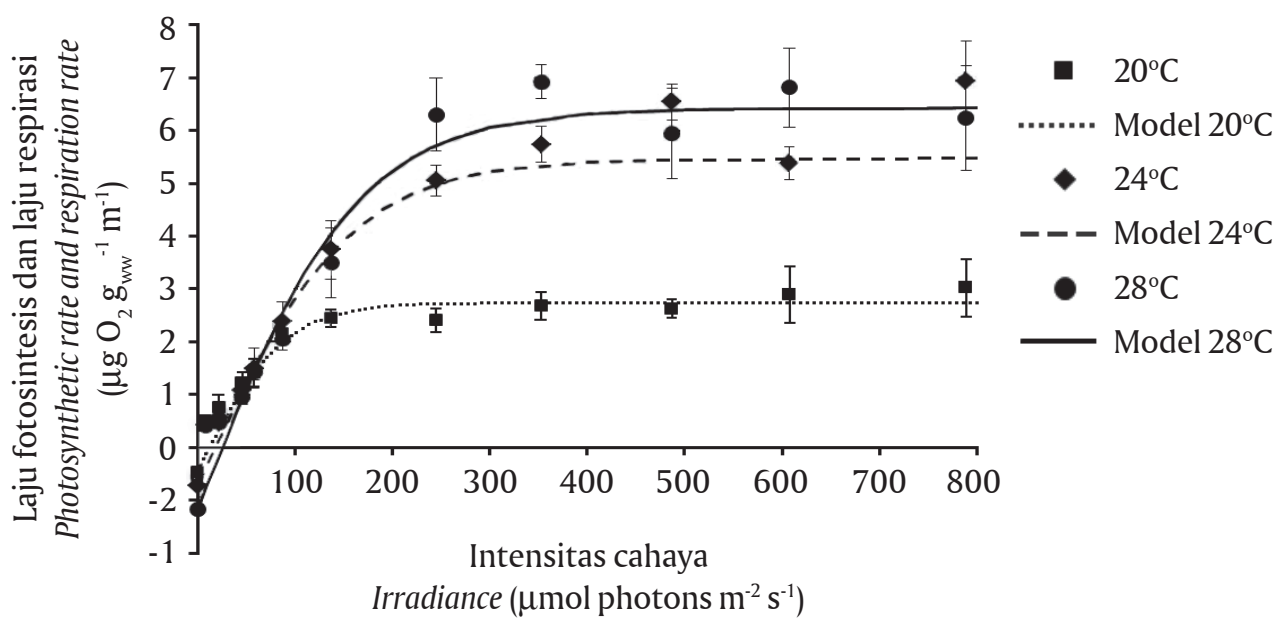

Gambar 8. Model kurva P-I Kappaphycus sp. (strain Sumba) pada suhu $20^{\circ} \mathrm{C}, 24^{\circ} \mathrm{C}$, dan $28^{\circ} \mathrm{C}$ yang diperoleh dengan cara memplotkan pada kurva $P-I$ dengan menggunakan rumus $P=\left\{P_{\max } \times \tanh \left(\alpha / P_{\max } \times I\right)\right\}+R_{\mathrm{d}}$

Figure 8. P-I curve model of Kappaphycus sp. (strain Sumba) at temperature of $20^{\circ} \mathrm{C}$, $24^{\circ} \mathrm{C}$ and $28^{\circ} \mathrm{C}$ obtained by fitting to $P$-I curve using equation of $P=\left\{P_{\max } \mathrm{x}\right.$ $\left.\tanh \left(\alpha / P_{\max } \times I\right)\right\}+R_{\mathrm{d}}$

dengan suhu habitat rumput laut yang diperoleh pada penelitian ini juga terjadi pada spesies sub-tropis. Laju fotosintesis tertinggi yang diukur berdasarkan perubahan oksigen terlarut untuk spesies daerah subtropis Meristotheca papulosa terjadi pada suhu $24^{\circ} \mathrm{C}$ (Lideman et al., 2011). Sementara itu, kisaran suhu yang optimal untuk aktivitas fotosintesis Meristotheca papulosa dan Meristotheca coacta yang diukur menggunakan metode chlorophyll fluorescence keduanya adalah $18^{\circ} \mathrm{C}-28^{\circ} \mathrm{C}$ (Lideman et al., 2012).

Model regresi non linear pada kurva fotosintesis versus suhu ( $P$-I curve) yang berbentuk hyperbolic tangent (Lobban \& Harrison, 1997) adalah bentuk umum yang hampir terjadi pada semua spesies makroalga (Gambar 8), bentuk seperti ini juga terjadi pada Kappaphycus alvarezii (Schubert et al., 2006). Nilai $P_{\max }$ menggambarkan potensi kapasitas fotosintesis dari suatu makroalga. Adanya perbedaan nilai laju fotosintesis maksimal $\left(P_{\max }\right)$ menunjukkan bahwa aktivitas fotosintesis sangat dipengaruhi oleh suhu, begitu juga dengan produksi oksigen, di mana pada tiap tingkatan suhu tertentu akan menghasilkan produksi oksigen yang berbeda pula. Dari tiga tingkatan suhu yang diujikan yaitu $20^{\circ} \mathrm{C}, 24^{\circ} \mathrm{C}$, dan $28^{\circ} \mathrm{C}$ diperoleh nilai $P_{\max }$ tertinggi pada suhu $28^{\circ} \mathrm{C}$, sebagai perbandingan nilai $P_{\max }$ Kappaphycus alvarezii (spesies berwarna hijau dan coklat berasal dari Filipina) dicapai pada suhu $30^{\circ} \mathrm{C}$ (Wobeser et al., 2001).

Intensitas cahaya jenuh $\left(E_{\mathrm{k}}\right)$ pada ketiga tingkat suhu menunjukkan nilai yang meningkat $(86,1$; 154,2; dan $162,4 \mu \mathrm{mol}$ photons $\mathrm{m}^{-2} \mathrm{~s}^{-1}$ ) sesuai dengan peningkatan suhu $\left(20^{\circ} \mathrm{C}, 24^{\circ} \mathrm{C}\right.$, dan $\left.28^{\circ} \mathrm{C}\right)$. Hal ini didukung juga oleh data nilai koefisien fotosintesis $(\alpha)$ yang meningkat sejalan meningkatnya suhu, $\alpha$ menggambarkan suatu kecepatan laju fotosintesis terhadap peningkatan cahaya sampai mencapai nilai laju fotosintesis maksimum $\left(P_{\max }\right)$. Nilai intensitas cahaya kompensasi $\left(E_{c}\right)$ di mana terjadi laju fotosintesis dan respirasi yang sama nilainya, juga meningkat sesuai dengan peningkatan suhu. Sebagai perbandingan, nilai $E_{\mathrm{k}}$ Kappaphycus sp. yang diukur dengan metode chlorophyll fluorescence yang menggunakan alat Pulse Aplitude Modulation (PAM)-chlorophyll fluorometry pada suhu $20^{\circ} \mathrm{C}, 24^{\circ} \mathrm{C}$, dan $28^{\circ} \mathrm{C}$ berturutturut adalah 113,6; 131,4; dan 149,3 $\mu$ mol photons $\mathrm{m}^{-2}$ $\mathrm{s}^{-1}$ (Lideman et al., 2013). Adanya perbedaan nilai $E_{\mathrm{k}}$ ini diduga karena pada metode chlorophyll fluorescence tidak melihat adanya laju respirasi $\left(R_{\mathrm{d}}\right)$ tetapi hanya melihat electron transport yang terjadi pada potosystem II proses fotosintesis. Namun demikian, nilai $E_{\mathrm{k}}$ ini mendekati nilai yang dihasilkan dengan metode perubahan oksigen terlarut yang dilakukan pada penelitian ini.

Saturation irradiance $\left(E_{\mathrm{k}}\right)$ dan compensation irradiance $\left(E_{c}\right)$ menunjukkan nilai yang meningkat dengan meningkatnya suhu air. Data ini memberikan gambaran bahwa kebutuhan cahaya akan meningkat jika suhu air meningkat. Informasi ini dapat digunakan untuk menduga bahwa kedalaman yang diperlukan untuk pemeliharaan Kappaphycus di laut pada musim kemarau berbeda dengan musim hujan karena perbedaan suhu air pada kedua musim tersebut. Namun demikian, penelitian skala lapangan perlu dilakukan dengan menggunakan model yang diperoleh dari pengamatan skala laboratorium seperti yang diperoleh pada penelitian ini. Selanjutnya, peningkatan 
kebutuhan cahaya yang sejalan dengan peningkatan suhu memberikan gambaran bahwa jika terjadi global warming di habitat alaminya, maka rumput laut ini akan tumbuh pada daerah yang lebih dangkal karena di daerah tersebut intensitas cahayanya relatif lebih tinggi. Nilai $E_{\mathrm{k}}$ (cahaya yang dibutuhkan dan menyebabkan laju fotosintesis maksimum), dan juga $E_{\mathrm{c}}$ (tingkat cahaya yang menunjukkan tingkat fotosintesis dan respirasi seimbang) dapat digunakan untuk menentukan kedalaman optimal dalam kegiatan budidayanya di laut dan dapat pula diaplikasikan pada kegiatan polikultur Kappaphycus sp. dengan udang atau ikan.

Dari sudut pandang akuakultur, perubahan kondisi lingkungan perlu diantisipasi dalam rangka perbaikan produktivitas budidaya Kappaphycus sp. Parameter $P_{\max }$ menggambarkan suatu kapasitas makroalga dalam melakukan aktivitas fotosintesis, sehingga untuk memaksimalkan produktivitas budidaya maka pengetahuan tentang suhu dan cahaya sangat penting untuk diketahui. Selanjutnya, suhu optimum yang diperoleh untuk aktivitas fotosintesis berhubungan erat dengan suhu yang ada di daerah areal budidayanya di Indonesia (Soegiarto et al., 1976; Nonji, 1993, Tomascik et al., 1997, Amin et al., 2008). Selain itu, cahaya yang dibutuhkan untuk mencapai laju fotosinesis maksimum pada suhu antara $28^{\circ} \mathrm{C}$ adalah $162,4 \mu \mathrm{mol}$ photons $\mathrm{m}^{-2} \mathrm{~s}^{-1}$, hasil ini berada dalam kisaran yang ada di sekitar lokasi budidaya di Punaga, Sulawesi Selatan yaitu pada siang hari dan kedalaman antara 0,5 sampai $1 \mathrm{~m}$ (700 $\mathrm{m}$ dari pinggir pantai) berkisar antara 1,482 sampai $109 \mu \mathrm{mol}$ photons $\mathrm{m}^{-2}$ $\mathrm{s}^{-1}$ (Lideman et al., 2013). Namun demikian, kondisi cahaya yang melebihi kebutuhan untuk aktivitas optimal kegiatan untuk fotosinsitesis (lebih dari 164,4 $\mu \mathrm{mol}$ photons $\mathrm{m}^{-2} \mathrm{~s}^{-1}$ ) diduga terjadi pada saat musim kemarau, hal ini terlihat dari warna Kappaphycus sp. yang dipelihara di bagian permukaan air mempunyai warna yang relatif lebih pucat jika dibandingkan dengan yang dipelihara agak dalam, sehingga diduga bahwa pada musim kemarau tidak perlu memelihara rumput laut ini di dekat permukaan air laut. Kondisi suhu dan cahaya optimum untuk proses fotosintesis yang berkorelasi erat dengan lingkungan budidaya di Indonesia ini menjelaskan mengapa kegiatan budidaya Kappaphycus sp. ini di Indonesia bisa berkembang dengan baik.

\section{KESIMPULAN}

Suhu optimum untuk aktivitas fotosintesis Kappaphycus sp. yang diperoleh adalah $28^{\circ} \mathrm{C}$ dan berhubungan erat dengan suhu yang ada di lingkungan budidayanya. Pada kisaran suhu $20^{\circ} \mathrm{C}-28^{\circ} \mathrm{C}$, laju fotosintesis mencapai tingkatan maksimum berkisar cahaya antara 86,1-162,4 $\mu \mathrm{mol}$ photons $\mathrm{m}^{-2} \mathrm{~s}^{-1}(E \mathrm{k})$, dan juga fotosintesis akan mencapai nilai yang sama dengan laju respirasi kisaran cahaya 12,6-25,2 $\mu \mathrm{mol}$ photons $\mathrm{m}^{-2} \mathrm{~s}^{-1}(E \mathrm{c})$. Adanya perbedaan nilai saturating irradiance $(E \mathrm{k})$ dan compensation irradiance $(E \mathrm{c})$ pada suhu yang berbeda menunjukkan bahwa dapat dilakukan pengaturan kedalaman pada kegiatan budidaya Kappaphycus sp. di Indonesia pada musim kemarau dan musim hujan. Perbedaan laju fotosintesis pada tingkat suhu dan cahaya yang berbeda menunjukkan bahwa produktivitas makroalga ini sangat dipengaruhi oleh perubahan lingkungan.

\section{UCAPAN TERIMA KASIH}

Penelitian ini disponsori oleh Grant-in-Aid for Scientific Research (\#22510033) yang berasal dari Menteri Education, Culture, Sport, Science and Technology (MEXT) Jepang dan Program Strategy for Fostering Young Scientist di Universitas Nagasaki yang disponsori oleh Special Coordination Funds for Promoting Science and Technology pada Menteri MEXT.

\section{DAFTAR ACUAN}

Amin, M., Rumayar, T.P., Femmi, N.F., Keemur, D., \& Suwitra, I.K. (2008). The assessment of seaweed (Eucheuma cotonii) growing practice of different systems and planting seasons in Bangkep Regency Central Sulawesi. Indonesian Journal of Agriculture, 1(2), 132-139.

Bixler, H.J., \& Porse H. (2011). A decade of change in seaweed hydrocolloids industry. J. Appl. Phycol., 23, 321-335.

Dawes, C.J., Mathieson, A.C., \& Cheney, D.P. (1974). Ecological studies of Floridian Eucheuma (Rhodophyta, Gigartinales). I. Seasonal Growth and Reproduction. Bull. Mar. Sci., 24, 235-273

Henley, W. J. (1993). Measurement and interpretation of photosynthetic light-response curves in algae in the context of photo inhibition and diel changes. J. Phycol., 29, 729-739.

Hung, L.D., Hori, K., Nang, H.Q., Kha, T., \& Hoa, L.T. (2009). Seasonal changes in growth rate, carrageenan yield and lectin content in the red alga Kappaphycus alvarezii cultivated in Camranh Bay, Vietnam. J. Appl. Phycol., 21, 265-272.

Jassby, A.D., \& Platt, T. (1976). Mathematical formulation of the relationship between photosynthesis and light for phytoplankton. Limnol. Oceanogr., 21, 540-547.

Lideman, Nishihara, G.N., Noro, T., \& Terada, R. (2011). In vitro growth and photosynthesis of three edible seaweeds, Betaphycus gelatinus, Eucheuma serra, and Meristotheca papulosa (Solieriaceae, Rhodophyta). Aquaculture Sci., 59(4), 563-571.

Lideman, Nishihara, G.N., Noro, T., \& Terada, R. (2012). 
Effect of temperature and light on the photosynthesis performance of two edible seaweeds, Meristotheca coacta Okamura and Meristotheca papulosa J. Agard (Solieraceae Rodhophyta). Aquaculture Sci., 60(30), 377-388.

Lideman, Nishihara, G.N., Noro, T., \& Terada, R. (2013). Effect of temperature and light on the photosynthesis as measured by cholorophyll fluorescence of Eucheuma denticulatum and Kappaphycus sp. (Sumba Strain) from Indonesia. Journal of Applied Phycology, 25(2), 399-406. DOI 10.1007/s10811-0129874-5.

Lobban, C.S., \& Harrison, P.J. (1997). Seaweeds ecology and physiology. Cambridge University Press. Cambridge, 384 pp.

Muraoka, D., Yamamoto, H., Yasui, H., \& Terada, R. (1998). Formation of wound tissue of Gracilaria chorda Holmes (Gracilaceae) in culture. Hokkaido Univ., Bull. Fac. of Fish., 49, 31-39.

Mollion, J., \& Braud, J.P. (1993). A eucheuma (Solieriacea, Rhodophyta) cultivation test on the South-west Coast of Madagaskar. Hydrobiologia, 260/261, 373-378.

Nishihara, G.N., Terada, R., \& Noro, T. (2004). Photosynthesis and growth rates of Laurencia brongiartii J. Agardh (Rhodophyta, Ceramiales) in preparation for cultivation. J. Appl. Phycol., 16, 303-308.

Nonji, A. (1993). Indonesian Ocean. Djambatan. Jakarta.

Ohno, M., Largo, D.B., \& Ikumoto, T. (1994). Growth rate, carrageenan yield and gel properties of cultured kappa-carrageenan producing red algae Kappaphycus alvarezii (Doty) in the subtropical waters of Shikoku, Japan. J. of Applied Phycol., 6, 1-5.

Ohno, M., Nang, H.Q., \& Hirase, S. (1996). Cultivation and carageenan yield and quality of Kappa- phycus alvarezii in the waters of Vietnam. J. Appl. Phycol., 8, 431-437.

Parker, H.S. (1974). The culture of the red algal genus eucheuma in the Philipine. Aquaculture, 3, 425-439.

Paula, E.J., Erbert, C., \& Pereira, R.T.L. (2001). In vitro growth rate of the carrageenophyte Kappaphycus alvarezii (Rhodophyta, Gigartinales). Phycol. Res., 49, 155-161.

Paula, E.J., Pereira, R.T.L., \& Ohno, M. (2002). Growth rate of the carrageenophyte Kappaphycus alvarezii (Rhodophyta, Gigartinales) introduced in subtropical waters of São Paulo State, Brazil. Phycol. Res., 50, 1-9.

Schubert, H., Anderson, M., \& Snoeijs, P. (2006). Relationship between photosynthesis and non-photochemical quenching of chlorophyll fluorescence in two red algae with different carotenoid compositions. Mar. Biol., 149, 1003-1013.

Serisawa, Y., Yokohama, Y., Aruga, Y., \& Tanaka, J. (2001). Photosynthesis and respiration in bladelet of Ecklonia cava Kjellman (Laminariales, Phaeophyta) in two localities with different temperature conditions. Phycological Research, 49, 1-11.

Soegiarto, A., Birowo, S., \& Sukarno. (1976). Map of Indonesian Ocean. Indonesian Science Institute.

Tomascik, T., Mah, A.J., Nonji, A., \& Moosa, M.K. (1997). The ecology of Indonesian seas. Periplus Editions (HK) Ltd. Jakarta.

Wobeser, E.A., Figueroa, F.L., \& Cabello-Pasini, A. (2001). Fotosintesis and growth of red and green morphotypes of Kappaphycus alvarezii (Rhodophyta) from the Philipines. Marine Biology, 138, 679-686.

Wu, C., Li, J., Xia, E., Peng, Z., Tan, S., Li, J., Wen, Z., Huang, X., Cai, Z., \& Chen, G. (1989). On the transplantation and cultivation of Kappaphycus alvarezii in China. J. Oceanol. Limnol., 7, 327-334. 